\title{
Profiling an unlocated source: Group 3d obsidian in prehistoric and early historic Near East
}

DOI:

10.1016/j.jasrep.2020.102533

\section{Document Version}

Accepted author manuscript

Link to publication record in Manchester Research Explorer

\section{Citation for published version (APA):}

Campbell, S., Healey, E., \& Maeda, O. (2020). Profiling an unlocated source: Group 3d obsidian in prehistoric and early historic Near East. Journal of Archaeological Science: Reports, 33.

https://doi.org/10.1016/j.jasrep.2020.102533

\section{Published in:}

Journal of Archaeological Science: Reports

\section{Citing this paper}

Please note that where the full-text provided on Manchester Research Explorer is the Author Accepted Manuscript or Proof version this may differ from the final Published version. If citing, it is advised that you check and use the publisher's definitive version.

\section{General rights}

Copyright and moral rights for the publications made accessible in the Research Explorer are retained by the authors and/or other copyright owners and it is a condition of accessing publications that users recognise and abide by the legal requirements associated with these rights.

\section{Takedown policy}

If you believe that this document breaches copyright please refer to the University of Manchester's Takedown Procedures [http://man.ac.uk/04Y6Bo] or contact uml.scholarlycommunications@manchester.ac.uk providing relevant details, so we can investigate your claim.

\section{OPEN ACCESS}




\title{
Profiling an unlocated source: Group 3d obsidian in prehistoric and early historic Near East
}

\section{Stuart Campbell ${ }^{a}$, Elizabeth Healey ${ }^{b}$ \& Osamu Maeda ${ }^{c}$}

a. (corresponding author) Department of Classics, Ancient History, Archaeology and Egyptology, University of Manchester, Oxford Road, Manchester M13 9PL, UK.

stuart.campbell@manchester.ac.uk

b. Department of Classics, Ancient History, Archaeology and Egyptology, University of Manchester, Oxford Road, Manchester M13 9PL, UK. elizabeth.a.healey@manchester.ac.uk

c. Faculty of Humanities and Social Sciences, University of Tsukuba, Tennoudai 1-1-1, Tsukuba, 3058571 Japan. maeda.osamu.gm@u.tsukuba.ac.jp

\begin{abstract}
Provenancing of obsidian artefacts has become an increasingly common practice in Near Eastern archaeology. However, knowledge of the geological sources of obsidian remains variable. The Group $3 d$ source remains the prime example; it was identified as chemically distinct in the 1960s and can be recognised as eastern Anatolian but it still lacks a specific geological location and has remained a minor detail in most publications. This article draws attention to the previously underappreciated importance of the source in later prehistoric periods, profiling assemblages of Group $3 \mathrm{~d}$ obsidian artefacts from Ubaid and Chalcolitihic Kenan Tepe and Halaf Domuztepe in south east Turkey, as well as more isolated artefacts from a further twelve sites. It reviews our knowledge of the chemical composition of Group 3d obsidian and its physical characteristics. The article also explores the spatial and chronological distribution of this type of obsidian, which had a particular significance from the $7^{\text {th }}$ millennium cal. BC onwards.
\end{abstract}

\section{Highlights}

- The Group 3d obsidian source is a distinctive type of obsidian, originating in eastern Anatolia.

- It was widely circulated in the ancient Near East, especially in later prehistoric and historic periods.

- It has been under-recognised in previous studies, largely due to small sample sizes and lack of study of later periods. 
Obsidian sourcing, pXRF, Near East, inter-regional contact

\section{1: INTRODUCTION}

The identification of exotic raw materials at archaeological sites far from their sources has been an archaeological technique for over 100 years. During the intervening period the methodologies for correlating artefacts with sources have become increasingly refined and, in comparison to other materials, the major sources of obsidian used in the Near East might be considered to be relatively well characterised. However, our evaluation and interpretation of the presence of obsidian from sites which utilised a wide diversity of sources is less well developed, and this is especially the case when a few artefacts from a particular source are present (Tykot 2011; Milić 2016). Sometimes these artefacts may be outliers from other better-known networks (Campbell and Healey 2018; Frahm et al. 2016) but in other instances they may be from sources that have simply remained less well documented.

Understanding this use of minority sources matters. It is true that, in most periods and over most of the Near East, obsidian from Göllüdağ East, Bingöl ( $A$ and $B$ ) and Nemrut Dağ provide the majority of obsidian in use at most sites but obsidian use can only partly, and probably not most importantly, be considered as an economic resource. Obsidian from less commonly used sources also occurs very regularly and may carry its own meanings and social significance. Indeed, the increasing diversity of the types of obsidian in use through time suggests that the exploitation of obsidian from less common sources may be part of a significant pattern (Campbell and Healey 2018). Obsidian provenance analysis is "not simply documenting source histories and the movement of obsidian in its own right (as raw material and/or end-product), but our ability to use the data as a proxy to reconstruct human actions" (Milić 2016, 101). Each source represented in an assemblage indicates a network through which communication as well as resource acquisition was enabled, rendering archaeologically visible chains of social relations along with geographical knowledge and movement. Understanding the complexities of connections in the Near East, and the meanings that might have been embedded in material culture, make it important to refine our knowledge of the lesser known sources of obsidian as much as the dominant ones. Here we profile our understanding of one geochemically defined group of obsidian artefacts in the Near East, which are without a known physical source, but which are becoming increasingly well documented. 
When provenancing of obsidian artefacts was first demonstrated in the Near East (Cann and Renfrew 1964; Renfrew et al. 1966), there were a number of groups which could be identified on the basis of their chemical composition but which had not been located on the ground. Most of the original ambiguities have long been clarified, and new sources have been identified both in archaeological assemblages and in source areas. Chataigner (1998) provides a useful narrative of the identification of the originally unlocated sources in the Near East. On a more global level, by 1998 it was broadly true that "the world of unknown sources of archaeological obsidian is rapidly shrinking" (Shackley 1998, 11). It would, however, be naive to pretend that issues around the geological sources of obsidian exploited in archaeological contexts in the Near East have been fully resolved. Some sources are only known from a small number of published analyses, for example the sizable complex of sources in north east Anatolia often distributed in secondary contexts along water courses (Brennan 2000; Chataigner and Gratuze 2014a and 2014b). Even in recent studies there are occasional artefacts that have a distinctive signature yet cannot be assigned to a known source, suggesting the tantalising possibilities of incomplete knowledge. In most cases, these are anomalies of individual artefacts. However, there is one geochemical group, identified in the 1960s, from which obsidian was regularly obtained by past communities in the Near East and whose exact location remains unknown. This is Group 3d (Renfrew et al. 1966, 33). Ironically, it is chemically highly distinctive and detectable by most analytical procedures.

While this article is not able to offer the definitive solution to the problem of the geographical location of the source, we suggest that the artefacts made from this obsidian are more frequent and meaningful than previously assumed. The identification of 278 artefacts made of Group $3 \mathrm{~d}$ obsidian in the archaeological assemblage from Kenan Tepe in south east Turkey (Campbell and Healey 2016) for the first time gives us the opportunity to profile the physical and chemical characteristics of a large number of artefacts of this source group. The further identification of 47 artefacts from Domuztepe, also in south east Turkey, provides a second assemblage of Group 3d obsidian. This allows us to examine the form in which the obsidian was obtained, the technologies used in its reduction and the type of artefacts made. A further 19 more isolated artefacts from twelve other sites have also been analysed, bringing the total of known Group 3d obsidian artefacts to 377, compared to the previous identification of only 33 examples. Six artefacts previously suggested to be made of Group 3d obsidian have also been reanalysed. From a chronological perspective, provenancing obsidian in the Near East has tended to focus on earlier prehistory, but our recent research on later material has started to show that the occurrence of artefacts of Group 3d obsidian has a distinct temporal profile and was 
used over a very wide region, albeit in rather small quantities at most sites (Fig. 1), being used in significant quantities from later prehistory to the early historic period.

\section{2: PREVIOUS IDENTIFICATION AND STUDY}

In the 1960s, Renfrew, Dixon and Cann identified artefacts of Group 3d obsidian at Ras Shamra, Dahran and Eridu, although the last of those was originally identified as Group 4c (Renfrew et al. 1966, Tables 1 and 2). They initially recognised it "on the basis of an exceptionally high content of rubidium and lithium" (Renfrew et al. 1966, 33). However, probably due to its rarity in analysed material, Renfrew and Dixon (1976) were willing to suggest that their chemically-distinct Group 3d might still come from the same geological source as their Groups $3 a$ and $3 b$, both also unlocated at that date but now identified with Meydan Dağ in eastern Turkey and Antiparos in the Aegean respectively. A further example from Tell Ubaid was analysed by INAA and, with a similarly high Rb value, was assigned to Group 3d (Wright 1969, Table 2). Wright also indicated that a possible Group 3d obsidian artefact came from Tilki Tepe (Wright 1968, Table 25; 1969, Table 5); however, it is difficult to verify this against the incompletely published compositional data. In the following decade, Epstein used INAA to analyse artefacts from Choga Mami and assigned two artefacts to his group T1 (Epstein 1977). While he did not explicitly identify his group T1 with Renfrew's Group 3d, it had a very similar profile with a high value for $\mathrm{Rb}$ (see also the reanalysis of both artefacts below).

In subsequent years, with the provenancing of a growing number of artefacts from Near Eastern sites, there has been a slow but steady increase in the number of artefacts with a similar composition that we would consider typical of Group 3d (Table 1). These have been identified at Tell Halaf (Schneider 1990, 70), Yarim Tepe II ( Francaviglia 1994, Table 6; Chataigner 1998, Table 9), Tell Halula (Pernicka et al. 1997, 119), Tell Kashkashok (Chataigner 1998, Table 9), Mashnaqa (Chataigner 1998, Table 9), Tell Atij (Chabot et al. 2001, Table 1), Umm Qseir (Maeda 2003, Table 38; Maeda 2010, Table 3), Tell Arbid Abyad (Drapalova 2010, 77), Abu Hureyra (Carter et al. 2012), Tell Beydar (Gratuze and Zambello 2014, Table 2), Tell Zeidan (Khalidi et al. 2016), Surezha (Khalidi et al. 2016), Arpachiyah (Khalidi et al. 2016), Arslantepe (Mouralis et al. 2018), Körtik Tepe (Kartal et al. 2018, 93) and Ein el-Jarba (Carter et al. 2020).

Some of these artefacts were originally categorised as unknown or tentatively associated with other poorly known source groups. For example, artefact HL12 from Halula was simply categorised as from an unknown source in the original publication (Pernicka et al. 1997, 119-120) and artefact 1106 from 
Arslantepe was identified as an outlier (Mouralis et al. 2018, supplementary data), while group T1 at Choga Mami was considered a source of unknown location (Epstein 1977, 92). However, in all the cases summarised in Tables 1 and 3, the high Rb values are very characteristic, usually in excess of 400ppm regardless of analytical technique. This is much higher than any published data for other sources or artefacts in Anatolia or Armenia. There are Yemeni sources which have comparably high $\mathrm{Rb}$ values, which from a geographical perspective might be feasible sources for sites in the Gulf and southern Mesopotamian, but they also have high $\mathrm{Zr}$ values (typically above 1300ppm) that do not occur among the Group 3d obsidians and make them clearly distinct (Khalidi 2010, Table 1). Other elements also hint at a distinctive compositional profile. Renfrew et al. $(1966,33)$ identified the tendency to high values of $\mathrm{Li}$. An association between a high $\mathrm{Rb}$ value and a high level of $\mathrm{Pb}$ was noted by Chabot et al. $(2001,253)$. Most recently, on the basis of three artefacts from different sites, Group $3 \mathrm{~d}$ obsidian has been noted as having "high contents of lithium, boron, rubidium and cesium" (Khalidi et al. 2016, 747).

The precise geological origin of Group 3d obsidian has so far not been identified. Renfrew and his colleagues simply suggested that the source was "possibly in Armenia", by which they meant eastern Turkey (Renfrew et al. 1966, 33). In her overview of obsidian in the Near East, Chataigner noted that Group 3d obsidian was often found together with obsidian from Bingöl and Nemrut Dağ, and more rarely, Meydan Dağ, suggesting a location in the region of Lake Van $(1998,317)$. This was echoed by Chabot et al. $(2001,253)$, who suggested the source was in the region of Lake Van, or a little further west. Most recently, there may be additional, unpublished geological work pointing to a potential location in the Bingöl area (Khalidi et al. 2016, 747).

\section{3: METHODOLOGY}

With one exception, the new analyses presented here were all carried out using portable X-ray fluorescence analysis (pXRF), an implementation of ED-XRF. This has been successfully used in a wide range of obsidian sourcing studies (Craig et al. 2007; Phillips and Speakman 2009; Nazaroff et al. 2010; Sheppard et al. 2010; Millhauser et al. 2015). In particular, it has been shown that it can effectively distinguish the major obsidian sources in the Near East (Forster et al. 2011; Frahm 2013; Milić 2014; Frahm 2014a and 2014b; Campbell and Healey 2016). In this study, analyses were performed using a Thermo Scientific Niton XL3t 980 GOLDD+. The instrument generates X-rays via a miniaturized $50 \mathrm{kV}$, $200 \mu \mathrm{A}$ tube with a silver anode. The XL3t GOLDD+ analyser has a silicon drift detector (SDD), with a resolution better than $155 \mathrm{eV}$. This model is similar to ones that have been successfully used for 
obsidian characterisation in the Near East and the Aegean by previous researchers (e.g. Frahm 2013 and 2014b; Frahm et al. 2014 a and 2014b; Le Bourdonnec at al. 2013, 2015; Mouralis et al. 2018).

In this study, the instrument's mining mode $(\mathrm{Cu} / \mathrm{Zn})$ was employed, which uses fundamental parameters as an internal correction scheme. A 90 second reading time has been used, composed of 20 seconds each using the main, low and high filters and 30 seconds using the light filter, the timings based on empirical tests to optimise speed and quality of readings. In many cases, multiple readings of the same artefact were taken to confirm that the measurements were repeatable; in these cases, the results presented here use a mean value. In most cases, readings were taken from samples more than $2 \mathrm{~mm}$ thick, avoiding issues related to thin artefacts (Davies et al. 2011; Orange et al. 2013; Le Bourdonnec et al. 2013). Where readings were taken on small or thin artefacts, as in the case with some from Domuztepe in particular, the absolute values tend to be inflated (cf Frahm 2016) and have not been used in the calculation of summary statistics; however, the attribution of these artefacts to Group $3 d$ appears secure due to the wide separation from other potential sources. Readings on international standards, always including SRM-278, were made within every session of analysis to monitor the consistency of the instrument over time.

While the raw results from the instrument are already subject to a built-in internal calibration, a second calibration, based on a linear regression, is needed to ensure comparability with other analytical techniques and minimise intra-instrument variability over time. A reference set of international standards was used. These were analysed as compressed powder pellets and included SRM-278 (obsidian), BIR-1a (basalt), BCR-2 (basalt), W-2a (diabase), DNC-1a (dolorite), JR-1 (obsidian), JR-2 (obsidian), RGM-2 (rhyolite) and BHVO-2 (basalt). For most elements, there is an excellent degree of correlation between our calibrated, measured results and this external reference set of standards, with a standard $\mathrm{R}^{2}$ statistic of above 0.95 . Obsidian artefact samples previously analysed by other major laboratories were also available and were used to confirm comparability of results. Except for a limited number of artefacts analysed in museums, all artefacts were cleaned in an ultrasonic bath in distilled water for 15 minutes before analysis.

Precision and accuracy were monitored over multiple readings against international standards. A subset is presented in Table 2 and Fig. 2 for the four elements that are of primary relevance to this article: $\mathrm{Rb}, \mathrm{Sr}, \mathrm{Zr}$ and $\mathrm{Pb}$. The first three are the elements most widely used to differentiate Near Eastern obsidian sources using ED-XRF and are particularly well measured using pXRF. While less generally useful for other sources, $\mathrm{Pb}$ proves to be a helpful discriminator for Group 3d in particular. Relative 
standard deviations, calculated over 10 repeat measurements, are generally very low for $\mathrm{Rb}, \mathrm{Sr}$ and $\mathrm{Zr}$, being below $2.2 \%$ in all but one instance. The relative standard deviation of Sr for JR-2 is higher at $7.2 \%$ and this is indicative of more variation in repeated measurements at lower concentrations of $\mathrm{Sr}$, present in JR-2 at a level of less than 10ppm. Although our set of standards is not particularly well optimised for the range of $\mathrm{Pb}$ values seen in Near Eastern obsidian, the relative standard deviation for $\mathrm{Pb}$ ranges from $10.3 \%$ to $16.4 \%$, so it is considerably less precise. However, this element remains a viable discriminator provided the difference between sources is relatively large.

Much of our work has compared the analysis of artefacts to the analysis of geological samples held in Manchester, using the same instrument and procedures, so that most source assignment takes places independently of the results of other analysts and laboratories (cf Frahm 2013, 1087). However, intertechnique compatibility is much more significant when considering all previous work in which Group $3 \mathrm{~d}$ obsidian has been identified, where we are interested in how distinct the composition of this sources is from other Near Eastern sources. Once the secondary calibration is applied, there is an excellent correspondence of the Manchester pXRF values to those of our set of standard reference materials for $\mathrm{Rb}, \mathrm{Sr}$ and $\mathrm{Zr}$; the $\mathrm{R}^{2}$ statistic is higher than 0.99 for all three elements (Fig. 2), by definition the same as the slope of the relationship. $\mathrm{Pb}$ is again less good but the $\mathrm{R}^{2}$ statistic is still above 0.93 . Some of the variation is probably caused by the instrumental precision for $\mathrm{Pb}$ but the lower number of calibration points may also be a factor.

Geological obsidian was available for comparison from all the known sources of obsidian in central and eastern Anatolia as well as the Armenian and Georgian sources, as part of the Manchester Obsidian Laboratory Source Reference Set, version 3.70, which comprises 1488 samples from 51 sources and sub-sources.

\section{4: RESULTS OF GEOCHEMICAL ANALYSIS}

Archaeological artefacts relevant to this discussion that have been analysed using pXRF come from Kenan Tepe, Choga Mami, Kavuşan Hoyük, Umm Dabaghiyah, Bouqras, Chagar Bazar, Ur, Jericho, Ras Shamra, Tal-i Jari A, Domuztepe, Salat Cami Yanı, Umm Qseir and Eridu. Most readings were carried out in the Manchester Obsidian Laboratory but some were analysed in museums. A further artefact from Mallowan's excavations at Chagar Bazar is included here, analysed using PIXE as a part of a different study at the AGLAE facility of the Centre de Recherche et de Restauration des Musées de France (for instrument details used in obsidian analysis see Calligaro et al. 2005). The results of our 
analyses of the artefacts identified as Group 3d show them to be very distinctive in a number of respects. This is most apparent in the composition of $\mathrm{Rb}$. The high values for $\mathrm{Rb}$ (a mean of $465 \pm 22.7$ ppm over all the analyses completed by the Manchester team using pXRF, when artefacts less than $2 \mathrm{~mm}$ thick are excluded) are different to other known source groupings and is also relatively tightly concentrated; this element alone is a strong indicator of this source for obsidian from sites in the Near East. $\mathrm{Pb}$ is also clearly distinct from other Near Eastern source groupings, with a mean of $66 \pm 4.54$ $\mathrm{ppm}$, when artefacts less than $2 \mathrm{~mm}$ thick are excluded. $\mathrm{A} \mathrm{Rb}-\mathrm{Pb}$ scatterplot is therefore an unambiguous way of identifying this group (Fig. 3a). However, other elements are also distinctive. The use of a $\mathrm{Sr}-\mathrm{Zr}$ scatterplot has become one of the more common ways of distinguishing many of the obsidian sources in the Near East. Although Group 3d is relatively close to Meydan Dağ, Kars Akbaba 2, Tendurek Diyadin, Pasinler and Muş in such a plot (Fig. 3b), it is both distinct and tightly clustered, primarily due to the higher level of Sr in Group 3d artefacts. It does, however, overlap with Kars Akbaba 2 obsidian if those two elements are used in isolation. It remains easily distinguished by both $\mathrm{Rb}$ and $\mathrm{Pb}$ and this emphasises the need to use a sufficiently wide set of elements in source determination.

Viewed across the elements that our pXRF study has focussed on, the composition of the Group 3d obsidian is strikingly regular (Table 3 and Supplementary Table). There seems to be little doubt that this is a chemically consistent and well-defined source. In the main, previous studies are consistent with these results (Table 1). $\mathrm{Rb}$ is always high, almost invariably above $450 \mathrm{ppm}$. $\mathrm{Pb}$ is generally consistent with our values, although some studies suggest values dropping to $43-44 \mathrm{ppm}$. It is unclear whether this represents variability due to the analytical technique or due to source variability. However, even 43-44 ppm is high for Pb in Near Eastern obsidian so it it is unlikely to present an issue for attribution. We consider the extremely low value for $\mathrm{Pb}$ obtained for a single sample by Drapalova $(2010,77)$ to be anomalous, perhaps even a typographic error. We also note that the values obtained for other elements by the Manchester pXRF study are close to those obtained by other laboratories who have previously analysed Group 3d material.

Although analyses of a wider range of elements have been less extensively published, being available only for legacy data and often incompletely reported for individual artefacts, this distinctiveness seems likely to persist. This was suggested for Li, B and Cs in Khalidi et al. $(2016,747)$. Li and B values from Khalidi et al. (2016) seem internally consistent, although the values of $301 \pm 7$ and $327 \pm 10 \mathrm{ppm}$ are higher than the values reported in Gratuze and Zambello (2014, Table 4). Where measured, Cs has 
values for Group 3d obsidian between 42 ppm and 49 ppm (Gratuze and Zambello 2014, Table 2; Khalidi et al. 2016, Table 1).

\section{5: PHYSICAL DESCRIPTION}

As well as forming a tight group geochemically, Group $3 \mathrm{~d}$ obsidian is often visually distinctive within an assemblage. Epstein described it as opaque and black in colour (Epstein 1977, 92) although the Kenan Tepe and Domuztepe artefacts show that the range of colour is slightly more varied. While it is indeed almost always opaque and most commonly black in colour, some pieces are dark red with black streaks (e.g. Fig. 4: kn-306, kn-381) or black with traces of red (e.g. Fig. 4: kn-406; Fig. 6: dt-0152 and dt-0187). In transmitted light, a few of the thinner artefacts have grey or red edges but are for the most part opaque. The surface of artefacts of Group 3d obsidian is typically less highly reflective than artefacts made of obsidian from other sources.

Group 3d obsidian has been considered to be of poor quality (e.g. Khalidi et al. 2016, 747). Certainly, the quality is variable. It frequently has a grainy texture, often with spherulitic or perlitic inclusions (Fig. 4: kn-500, kn-873), although this is not a universal property as some pieces appear free of phenocrysts and have a silky feel or texture (Fig. 4: kn-012, kn-400 and Fig. 6: dt-0067). The group 3d obsidian at Domuztepe seems, on the whole, to be less grainy than that from Kenan Tepe but still stands out from obsidian from other sources because of its opacity and low reflectivity. Its appearance thus means that the presence of Group 3d obsidian within an assemblage can often be suspected on the basis of the visual appearance, given sufficient familiarity with the range of the visual characteristics of the other obsidians present. Differences in quality may depend on internal variations within the primary obsidian flow and perhaps reflect the care with which material was collected.

A high proportion (c. 37\%) of the Group 3d artefacts from Kenan Tepe has patches of an outer crust or cortex. This varies from bubbly (e.g. Fig. 4: kn-403) to smoother (e.g. Fig. 4: kn-398) and is sometimes scored (e.g. Fig. 4: kn-398). None of the artefacts appear to be made from heavily waterworn nodules, which suggests that they were not from a riverine context, but a degree of weathering can be observed. A few pieces have extensive areas of cortex and this allow us to suggest that some of the original nodules were quite small and rounded, between c. 60 and $70 \mathrm{~mm}$ in diameter (e.g. Fig. 4: kn-403), while others are more angular (e.g. Fig. 4: kn-690), something also noted at Domuztepe. The small size of the original nodules probably accounts for the high proportion of artefacts with cortex and suggests that at Kenan Tepe it was brought to the site in a raw or unprepared state. 


\section{6: GROUP 3D IN ARCHAEOLOGICAL CONTEXT}

Until recently only a few artefacts from an individual site have been identified as Group 3d. The new data from Kenan Tepe and, to a lesser extent, Domuztepe allow us not only to profile the physical characteristics of Group 3d obsidian but also to examine reduction practices.

\section{1: Kenan Tepe}

Kenan Tepe is located on the north bank of the Tigris River, approximately $15 \mathrm{~km}$ west of the TigrisBatman confluence in the Diyarbakir province, south east Turkey (Fig. 1). Excavated occupation dates from the Ubaid Period to the Middle Bronze Age, c.4,600 to 1,800 cal. BC (Parker et al. 2006; 2009; Parker forthcoming). Obsidian accounts for almost $25 \%$ of the raw material used in the chipped stone assemblage, about $39 \%$ of which ( 882 artefacts) we have been able to analyse by pXRF (Campbell and Healey 2016). The most common obsidian originated from Nemrut Dağ (38.4\%) and that from Bingöl A and Bingöl B each contributed $13.8 \%$. Nine other sources account for just over $2 \%$ of the assemblage. The surprise was that 278 artefacts (31.5\%) were made of obsidian that can be identified as Group 3d. This obsidian artefacts are often substantial (the average weight being $4 \mathrm{~g}$ per object compared to approximately $1.6 \mathrm{~g}$ for the other obsidians). Although its contribution fluctuated through time, it consistently formed a significant proportion of the assemblage in the Ubaid, the Late Chalcolithic and the Middle Bronze Age phases, supplanting that from Nemrut Dağ in Ubaid 4 (Campbell and Healey 2016, Fig. 8). Five of these artefacts of Group 3d obsidian had been previously analysed using EMPA (Frahm forthcoming), which assigned them to the Muş source. However, this is simply due to the fact that the EMPA did not measure Rb, owing to the high level of Si in obsidian (Frahm 2010, 372). This does emphasise the fact that, as with many other sources, Group 3d attributions can be missed if key elements are not measured.

The techno-typological profile of the artefacts provenanced to source Group 3d (summarised in Fig. 5), are markedly different from those made from Nemrut Dağ or Bingöl obsidian. Six cores were recorded at Kenan Tepe, five of which are of Group 3d obsidian (Campbell and Healey 2016, Table 6). Flakes predominate amongst all types of obsidian (Campbell and Healey 2016, Table 6) but, in contrast to the flakes made of obsidian from other sources, cortex was recorded on over a third of the group $3 d$ flakes, some of which have quite extensive patches (Fig. 4: kn-001, kn-307, kn-319, kn-403, kn-398 and kn-690). Some are early stage removals suggesting that raw nodules were brought to Kenan Tepe; on-site reduction is corroborated by concentrations of micro-debitage likely to be of Group $3 d$ 
obsidian in one trench dating to the Ubaid 4 period (Campbell and Healey 2016). The scars on the cores (fig. 4: kn-034), the stigmata on the flakes, a number of hinged terminations and the robustness of some of the inner flakes (Fig. 4: kn-013, kn-028 and kn-204) suggest that the nodules were likely reduced by direct percussion, probably using a softish percussor. Although there are some pieces with blade-like proportions (for example Fig. 4: kn-012, kn-0437), there is no evidence of blade production or the use of pressure reduction.

Modification is rare and no formal tools are made from Group 3d obsidian. Retouch is irregular and is not always clearly distinguishable from post-depositional damage; it is mostly confined to the edges of artefacts (Fig. 4: kn-381, kn-437 and kn-475).

Although the assemblage of Group 3d obsidian from Kenan Tepe is by far the most comprehensive that has been recorded to date, it does not necessarily mean that its profile is typical of other assemblages. We note for instance that more blades are present elsewhere (Supplementary Table 1) and that the texture of the obsidian tends to be less coarse than at Kenan Tepe. It may be that the texture of a nodule improves towards the interior and, if this is the case, the presence of the early stage pieces at Kenan Tepe may have exaggerated our impression.

We have suggested that at Kenan Tepe the group $3 \mathrm{~d}$ obsidian was probably obtained directly from source, but, in view of its relatively poor quality it is harder to explain why it was exploited so extensively or why there was a preference for it at a specific time in the Ubaid 4 levels; 120 artefacts of Group 3d obsidian came from one trench, over half of which were recovered from a single locus (Healey forthcoming; Campbell and Healey 2016). It may simply be that there were short-term interruptions in access to the more usual obsidian from the Nemrut Dağ and Bingöl sources or it may reflect a group of people represented by this locus, who had some affiliation (symbolic or socioeconomic) with the Group 3d obsidian or its source locality.

\section{2: Domuztepe}

The second site that has produced larger than expected quantities of Group 3d obsidian is Domuztepe, in south east Turkey, $25 \mathrm{~km}$ south of the modern city of Kahramanmaraş. The prehistoric occupation of the site dates from the Ceramic Neolithic through to the late Halaf (c.6,400-5,450 cal. BC). Obsidian accounts for about 18 to $20 \%$ of the lithic raw materials used and it has been recorded in most contexts, although most of the provenanced obsidian comes from the Halaf I to Halaf II phases at the site (c.6,100-5,450 cal. BC). Group 3d obsidian has been identified in two independent sets of 
analyses, both carried out using pXRF, and we can correct two misattributions made in a previous publication. The first study was an opportunistic analysis carried out in the field and in Kahramanmaraş Museum by Joseph W. Lehner in 2009 and 2010, using a Bruker Tracer III-V instrument. While these analyses are not fully calibrated, in almost all cases the obsidian source can be determined with a reasonable level of confidence and have been checked against repeat analyses of selected artefacts that were exported for study in more controlled circumstances. The results that are relevant here are very clear, as the Group $3 \mathrm{~d}$ material has the expected and very distinctive high level of $\mathrm{Rb}$, so that these artefacts may be included as examples of Group 3d obsidian. However, the measurements should properly be considered semi-quantitative. The second set of pXRF analyses was carried out on artefacts at the University of Manchester as part of this study, using the methodology outlined above. One artefact (dt-0067) had previously been analysed by Lehner and the identification was confirmed. An additional 37 artefacts were identified as made of Group $3 \mathrm{~d}$ obsidian, bringing the total number of artefacts from this source at Domuztepe to identified to 47.

Two of these artefacts were also analysed by Ellery Frahm and published in collaboration with two of the present authors (Frahm et al. 2016). One (dt-0085) was analysed using EPMA and identified as coming from Muş. The second (dt-0067) was analysed using pXRF and identified as coming from Kars Arpaçay. The potential for these misidentifications has been discussed above, and the issue lies with the elements analysed and comparative source data set rather than the wider methodologies employed. Both artefacts have been reanalysed in the Manchester Obsidian Laboratory study and these values are reported here (Table3; Supplementary table). The $\mathrm{Rb}$ and $\mathrm{Pb}$ values are entirely consistent with a Group 3d attribution and, for these elements, differ significantly from both the Muş and Kars Arpaçay sources.

Unlike Kenan Tepe, despite the relatively high absolute number, Group 3d is only small component of the overall obsidian assemblage from Domuztepe. It makes up just over $4 \%$ of the analysed obsidian, still a significant proportion of the minority sources utilised at the site (the majority of the obsidian came from Bingöl B, Nemrut Dağ, Bingöl A and Göllüdağ East; as at Kenan Tepe obsidian from 10 other sources was present in small quantities). Group 3d obsidian comes from all phases of occupation from which we have analysed material so the supply seems to have been sustained over a relatively long period of time.

The artefacts of Group 3d obsidian from Domuztepe have a different techno-typological profile from those found at Kenan Tepe (Fig. 5). They also generally seem to be less grainy in texture although a 
similar range of colours are present. The presence of a core suggests that at least some flake and blade production was carried out at Domuztepe, although there are fewer early stage pieces (Fig. 6: dt-0160 and dt-0169) than at Kenan Tepe, which could suggest that it was acquired in a semi-processed state.

Blades form a much larger proportion of the removals that they do at Kenan Tepe and tend to be more regular (Fig. 6: dt-0146, dt-0159, dt-0238 and dt-0241). The most regular blades are made on obsidian with red mottling (Fig. 6: dt-0152 and dt-0187). Modified pieces include a blade with a heavily worn corner (Fig. 6: dt-0245), an arrowhead (Fig. 6: dt-1256), which is made of quite spherulitic obsidian but is finely flaked, probably by pressure retouch, and a chunk which has a flat and seemingly ground and polished surface (Fig. 6: dt-0067).

Both Kenan Tepe and Domuztepe acquired obsidian from a wide range of sources, however for Group $3 \mathrm{~d}$ obsidian the acquisition mode at Domuztepe (i.e. that it was acquired in a semi-prepared state) seems similar to that for the other obsidians and contrasts with that at Kenan Tepe.

\section{7: THE CHRONOLOGICAL AND REGIONAL OCCURRENCE OF GROUP 3d OBSIDIAN}

Other examples of artefacts made of Group $3 \mathrm{~d}$ obsidian occur in small quantities but from a wide range of sites (Tables 1 and 3 ).

The earliest known example comes from a late Epipaleolithic context at Körtik Tepe in the Upper Tigris valley in south east Turkey, dating to the $11-10^{\text {th }}$ millennia cal. BC (Kartal et al. 2018, 93). The technological details and composition of this artefact have not yet been published. This occurrence is

substantially earlier than other examples of this source. Other obsidian from this site has been attributed to Bingöl A and B, and Nemrut Dağ, with a "very small proportion" from Muş (Kartal et al. 2018, 93; Carter et al. 2013). If, as seems likely, Group 3d obsidian also originates within this region, its presence might be understood as relatively local use and perhaps acquired during the seasonal exploration of the landscape to the north of the site.

Chronologically, the next provenanced example is at a considerable distance from the potential source area, at Ras Shamra on the north Levantine coast (Renfrew et al. 1966, Table II). This blade comes from the layers below $9.60 \mathrm{~m}$ deep in the palace sounding (Renfrew archive in The Museum of Archaeology and Anthropology, Cambridge), which places it in a pre-pottery Neolithic context to be equated with Ras Shamra phase V C 2 (Kinschke 1962, 261-262; de Contenson 1992, 13). While the exact date of this phase is unclear, it probably belongs to the end of the pre-pottery Neolithic period 
and perhaps dates to the very end of the $8^{\text {th }}$ or the early $7^{\text {th }}$ millennium cal. BC. This occurrence anticipates the start of a period of sustained use of Group $3 \mathrm{~d}$ obsidian by the mid- $7^{\text {th }}$ millennium cal. $\mathrm{BC}$ as a consistent, albeit minority, source at archaeological sites over northern Mesopotamia and the northern Levant. The five examples (of which three are blades) from Abu Hureyra in northern Syria, in phases 7 and 8, date to the Ceramic Neolithic, early to mid- $7^{\text {th }}$ millennium cal. BC (Carter et al. 2012). Four blades made from Group 3d obsidian were excavated at Bouqras from contexts of the mid- $7^{\text {th }}$ millennium cal. BC on the middle Euphrates in eastern Syria. At a similar or slightly later date, at Umm Dabaghiyah, a single blade fragment of Group 3d obsidian was identified, the $515^{\text {th }}$ artefact to be analysed in an assemblage of 681 pieces of obsidian. At the broadly contemporary site of Salat Cami Yanı in south east Turkey, two further examples of Group 3d obsidian have been identified and the published example from Tell Halula in northern Syria is probably also of a similar date (Pernicka et al. 1997, 119). The earliest identified examples found at Domuztepe date to c. 6,200 cal. BC.

In the following millennia, Group 3d obsidian continues to occur regularly, if sparsely, at a wide variety of sites in Mesopotamia. The low numbers are certainly attributable as much to the low frequency of geochemical analysis of obsidian from this time period as to the actual situation. Many assemblages are entirely unprovenanced and, where studies have been done, sample size has often remained limited. However, the regularity of occurrence of Group 3d obsidian is significant. Kenan Tepe may remain an exceptional site, with proximity to the source and local factors lying behind the high occurrence of obsidian of this source. On the other hand, there seem to be a much wider range of sites at which Group 3d was still a significant contributor to the total obsidian assemblage. Contemporary with the early $6^{\text {th }}$ millennium cal. BC Halaf period examples at Domuztepe are the occurrence of 4 artefacts of Group 3d obsidian at Yarim Tepe II (Francaviglia 1994; Chataigner 1998) and one at Arpachiyah (Khalidi et al. 2016) in northern Iraq as well as examples at Umm Qseir and Tell Arbid Abyad (Drapalova 2010) in northern Syria. The artefact from Tell Zeidan is slightly later in the Ubaid period (Khalidi et al. 2016) in the $5^{\text {th }}$ millennium cal. BC.

What is equally striking is the wide geographical range over which Group 3d obsidian occurs. This includes not only southern Iraq, with occurrences at Eridu and Tell Ubaid, probably both during the Ubaid period (c.5,200-4,500 cal. BC), but also in the Gulf and south west Iran. The blade from Dahran is described as "Ubaid" in date (Renfrew et al. 1966, Table II). The artefact analysed in this study from Tal-I Jari A unfortunately does not have a precise stratigraphic position but the only levels of this site that were excavated were Ceramic Neolithic or Chalcolithic in date (Egami et al. 1977). 
The importance of Group 3d obsidian appears to continue into the historic period, although the quantity of data unfortunately becomes even more sparse due to the lack of analysis. The example from Arslantepe comes from Period VIA, towards the end of the $4^{\text {th }}$ millennium cal. BC (Mouralis et al. 2018). The artefacts analysed in this study from Ur in southern Mesopotamia (Table 3; Fig. 7) lack contextual information but probably date from within the $3^{\text {rd }}$ and $2^{\text {nd }}$ millennia BC. Although our study of obsidian from this period in southern Iraq is ongoing, it is clear that the five blade fragments from Ur suggest that Group 3d was a significant source of obsidian. In northern Mesopotamia too there are hints of the importance of this source. Two Group $3 d$ artefacts have been identified in early $3^{\text {rd }}$ millennium BC levels at Tell 'Atij in north east Syria; artefact S3789 is from level VII while S518 is from a context of undetermined date, but presumably within the Ninevite 5 period as this is the main occupation on the site (Chabot et al. 1991). Since only six artefacts were provenanced, this suggests that amongst the admittedly rare use of obsidian at the site the Group $3 \mathrm{~d}$ source was of some significance. Similarly, at Early Bronze Age Tell Beydar a little further north in Syria, two of the 12 analysed pieces of obsidian were of Group 3d obsidian (Gratuze and Zambello 2014), again suggesting the regular use of this supply. One of the two artefacts of Group 3 composition from Umm Qseir comes from a context that is Mitanni in date (c. 1500-1300 BC), although it may be redeposited from the underlying Halaf occupation.

While obsidian also remained in use in the Levant during later periods, source studies are rare. However, we have identified two examples of Group 3d obsidian from the Early Bronze Age levels at Jericho in the southern Levant (Table 3). Two pieces of Group 3d obsidian have recently been identified at Ein el-Jarba (Carter et al. 2020). While the example from a Persian/Hellenistic context almost certainly is redeposited material from earlier contexts, the second example is from an Early Bronze I deposit. The suggestion in the original publication that this is also residual from the earlier Wadi Rabah occupation is certainly very plausible (Carter et al. 2020), which would parallel the wide geographical distribution of Group 3d obsidian at that time. However, it remains the case that Group 3d obsidian is not documented in the southern Levant prior to the Early Bronze Age, which might suggest that the discovery context for this item may be correct. It certainly seems probable that, as more material is analysed, Group 3d obsidian will be revealed as a significant source of obsidian during proto-historic and historic periods in the Levant, as in Mesopotamia.

\section{8: CONCLUSIONS}

We have been able to greatly increase the number of artefacts known to be made from Group 3d obsidian as well as the number of sites at which they occur. This has allowed us both to confirm the 
chemical signature of the source with increased confidence and to profile the physical characteristics of this type of obsidian. However, the precise geographical location for Group 3d obsidian remains elusive. Chataigner's suggestion of a location in the very general region of Lake Van remains plausible (Chataigner 1998, 317) and a recent survey of Eastern Anatolian sources has proposed the area of Bingöl itself (Khalidi et al. 2016, 747). The evidence from Kenan Tepe confirms the association of Group 3d obsidian with material from Bingöl and Nemrut Dağ, which are present at the site in similar amounts; however, the low quantity of Meydan Dağ obsidian at the site also suggests that the Group $3 \mathrm{~d}$ source should be sought in the narrower region between Bingöl and Nemrut Dağ. Other than the Muş source, obsidian sources in this location remains relatively poorly studied (Chataigner et al. 2014) and an obsidian outcrop which is as yet unsampled is not impossible. We would argue that it is possible that the Group 3d source may have been more accessible to Kenan Tepe than the other two main sources simply on the basis that this obsidian was acquired in a raw state. The fact that it is of lower quality than the obsidians from the other large contributors, Bingöl and Nemrut Dağ, may indicate that it was used to fulfil a need at particular times, especially given its dominance in an Ubaid phase 4 house.

Although the Group 3d obsidian source was occasionally used, even at sites presumed to be close to source, such as Körtik Tepe, its presence appears to have been very limited in earlier prehistory. However, from the mid- $7^{\text {th }}$ millennium cal. BC, it started to be exploited regularly and this continued over the following millennia in an increasingly wide area. Other than at Kenan Tepe, Group 3d obsidian occurs as a small portion of the overall assemblage at individual sites. This fits into a wider pattern of obsidian use (Campbell and Healey 2018). Although a small number of sources continued to dominate obsidian supply across Mesopotamia and the Levant (principally Nemrut Dağ, Bingöl A, Bingöl B and Göllüdağ East in different proportions), a range of minority sources also appear with increasing regularity. Group 3d obsidian almost always occurs with obsidian from other sources in south east Anatolia and occasionally with obsidian from north east Anatolia and Armenia; some sites, mainly in the Euphrates region or the Levant, also have obsidian from central Anatolia. While shifts in dominant sources also occur, this constitutes a widespread and consistent pattern of an increasing diversity of obsidian supply. In this, the exploitation of Group 3d obsidian parallels the use of obsidian from other minority sources in Mesopotamia and the Levant, including the sources in north east Anatolia, Armenia and Georgia.

Without knowing the specific location from which the Group 3d obsidian came, it is obviously difficult to discuss the circumstances in which a less widely used obsidian sources came into more prominence. 
However, it is also the case we still know comparatively little about the way in which even the more dominant obsidian sources were exploited. Although we have increasing information on Göllüdağ East (Balkan-Atlı et al. 2008; Binder et al. 2011) and Nemrut Dağ (Robin et al. 2016), unanswered questions remain around the specific outcrops exploited (Frahm 2020), which communities had access and how wider distribution networks were supplied. The value placed on the physical properties of obsidian might have changed through time. While Bingöl and Nemrut Dağ obsidian is typically higher quality, the evidence from Kenan Tepe and Domuztepe shows Group 3d obsidian to have been suitable for a diversity of uses and its slightly different appearance may have been preferred for some purposes. While to our prejudiced eye, Group 3d obsidian doesn't seem to be employed for anything special, it may have had symbolic significance that maintained its use over a long period. While Group $3 d$ obsidian was obviously accessible earlier, it is possible that physical access became easier during the $7^{\text {th }}$ millennium cal. BC, perhaps through landscape changes that made access more practical. Equally, changing values ascribed to obsidian as a raw material may have sometimes reduced the incentive to obtain raw material only from the highest qualtity sources and established exchange networks, when a lesser but still functional quality of obsidian might have been obtained with slightly less effort from a more accessible location (cf Chataigner and Barge 2008).

It is not unreasonable to suppose that the nature of obsidian acquisition networks themselves was changing. This may have happened in different ways and for different reasons, with new types of longdistance links developing, solidifying social groupings while also restricting access to previously preferred sources. A wider range of communities may have been participating in these exchange networks, including communities living close to alternative sources of obsidian and the networks themselves may have been becoming more extensive. Lateral exchange may also have become more important, with more repeated exchange of obsidian within a particular region rather than simple reliance on vertical distribution from a source. This may have enabled obsidian from a minority source, only entering the distribution network in bulk at a small number of sites, to diffuse in small quantities over a much wider area over time. It is also possible, perhaps particularly in later periods, that obsidian was being obtained as part of embedded procurement, in which obsidian was obtained alongside other activities, which might include both herding and trade/exchange of other commodities, including metal by the $5^{\text {th }}$ millennium cal. BC. This might have started to bring smaller sources to prominence simply because they were closer to the locations at which these other activities occurred.

Kenan Tepe is the first discovery of the large-scale use of Group 3d obsidian but it is almost certainly not a unique example. The relatively high quantity of this type of obsidian at this site may well reflect 
factors specifically related to how obsidian was obtained at a settlement not very far from the source. While different mechanisms may have been used, obsidian might have been obtained through direct access to the sources, perhaps embedded in a cycle of pastoral movements (Campbell and Healey 2016, Fig. 11) or through direct social contact with groups close to the source. Short-term fluctuations, possibly through localised conflict or disruption to social relationships as well as seasonal factors such as snowfall, might have required periodic use of alternative sources. It is noticeable that it is only in the Ubaid 4 phase at Kenan Tepe that Group 3d obsidian makes up the majority of obsidian in use (Campbell and Healey 2016, Fig. 8). This may well reflect such a short-term fluctuation. However, given the limited area in which this phase is represented, the dominance of Group 3d obsidian may also reflect the acquisition strategy of a sub-community in the settlement, in which specific connections and mobility practices may have resulted in an unusual pattern of resource procurement.

Whatever the reason, it is clear that the Group $3 \mathrm{~d}$ obsidian source deserves more prominence in the discussion of obsidian sources in the Near East. It has often been relegated to a footnote or a curiosity within a wider focus on the major sources of obsidian. In part, this is due to the small number of artefacts of obsidian that have often been analysed from individual assemblages. Small sample sizes inevitably under-represent minority sources. It is also a product of a systematic concentration on the archaeology of the early Neolithic rather than later prehistory, which has resulted in under-sampling of exactly the period in which Group $3 d$ obsidian is most used. While the significance of the use of Group 3d obsidian obviously suggests that there should be further ground survey to locate its source, it also emphasises the importance of analysing larger assemblage if we are to appreciate the role of minor sources of obsidian in the ancient Near East.

\section{Aknowledgements}

We are very grateful to a wide range of individuals and institutions who have contributed to this research. Ellery Frahm and two anonymous reviewers provided helpful comments on the paper, but all errors are the authors' own. The core of our database of geological obsidian samples was provided by Professor Akihiko Mochizuki, National Institute of Technology, Numatsu College, including material collected by Katsuji Kobayashi. Additional samples from Turkey, Armenia and Georgia have come from Christine Chataigner, F.-X. Le Bourdonnec, Michael Glascock, Kristine Martirosyan-Olshansky and Peter J. Leeming, as well as from collections made by the authors. The late Professor Bradley Parker, University of Utah provided access to the obsidian artefacts from Kenan Tepe, and Diyarbekir Mușeum and Turkey's Ministry of Culture and Tourism kindly permitted the analysis of this assemblage. The material from Domuztepe was also analysed with the permission and assistance of the Ministry of 
Culture and Tourism in Turkey. We are particularly grateful to Joseph W. Lehner both for the initial pXRF analyses of the material from Domuztepe and for providing us with the full data. Additional analysis on the Domuztepe obsidian was carried out by Ellery Frahm. The pXRF instrument used in this study was provided by the University of Manchester. The sample from Chagar Bazar was analysed at the AGLAE facility of the Centre de Recherche et de Restauration des Musées de France (C2RMF), with laboratory access provided through the FIXLAB-CHARISMA programme; we thank Thomas Calligaro and his colleagues for assistance with the analysis. We are grateful to Paul Collins and Imogen Gunn for providing access to material in the collections of the Ashmolean Museum, Oxford and the Museum of Archaeology and Anthropology, Cambridge respectively. Peder Mortensen and Susan Kerner helped organise the loan of obsidian artefacts from Umm Dabaghiyah that are housed in the University of Copenhagen and Olivier Nieuwenhuyse arranged the loan of obsidian artefacts from Bouqras from Leiden University.

\section{Figures}

1. Sites at which Group 3d obsidian has been identified. Yellow triangles indicate obsidian sources (named when mentioned in the text) and dots indicate sites at which Group 3d obsidian has been identified).

2. Correlation of key elements analysed using PXRF with international standards

3a. $\mathrm{Rb}-\mathrm{Pb}$ scatterplot, with $90 \%$ ellipses, comparing Group 3d obsidian with all other sources in central and eastern Anatolia, Georgia and Armenia.

3b. Sr-Zr scatterplot of Group 3d obsidian and selected eastern Anatolian obsidian.

4. Artefacts from Kenan Tepe made from Group 3d obsidian.

5. Typology of Group 3d obsidian artefacts from Kenan Tepe and Domuztepe.

6. Artefacts from Domuztepe made with Group 3d obsidian.

7. Artefacts from other sites made of Group 3d obsidian.

\section{Tables}

1. Previously published Group 3d obsidian (selected elements, units are ppm); see supplementary table for complete data.

2. Comparison of Manchester Obsidian Laboratory pXRF measurements with international standards SRM-278, RGM-2 and JR-2 for Rb, Pb, Sr and Zr. Units are ppm. 
3. Analyses of Group 3d obsidian. The Kenan Tepe is summarised from Campbell and Healey 2016. An* after the artefact code indicates an artefact that is $<2 \mathrm{~mm}$ thick; the values given for these readings may be inflated. Units are ppm.

\section{Supplementary tables}

1. Full details of all Group 3d obsidian (all elements, units are ppm)

\section{Bibliography}

Binder, D., Gratuze, B., Mouralis, D., Balkan-Atlı, N., 2011. New investigations of the Göllüdağ obsidian lava flows system: a multi-disciplinary approach. J. Archaeol. Sci., 38(12), 3174-3184. https://doi.org/10.1016/j.jas.2011.05.014.

Brennan, P., 2000. Obsidian from volcanic sequences and recent alluvial deposits, Erzurum district, north-eastern Anatolia: chemical characterisation and archaeological implications. Ancient Near Eastern Studies 37, 128-152. https://doi.org/10.2143/ANES.37.0.1083.

Balkan-Atlı, N., Binder, D., Gratuze, B., 2008. Göllü Dağ (Central Anatolia): Obsidian Sources, Workshops and Trade. Anatolian Metal IV, Bochum, 203-210.

Calligaro, T., Dran, J.-C., Dubernet, S., Poupeau, G., Gendron, F., Gonthier, E., Meslay, O., Tenorio, D., 2005. PIXE reveals that two Murillo's masterpieces were painted on Mexican obsidian slabs. Nucl. Instrum. and Methods in Phys. Res. B, 240, 576-582.https://doi.org/10.1016/j.nimb.2005.06.155. Campbell, S., Healey, E., 2018. Diversity in obsidian use in the prehistoric and early historic Middle East. Quaternary International 486A, 141-154. https://doi.org/10.1016/j.quaint.2017.09.023 Campbell, S., Healey, E., 2016. "Multiple Sources: The pXRF Analysis of Obsidian from Kenan Tepe, S.E. Turkey." J. Archaeol. Sci.: Reports, 10, 377-89. https://doi.org/10.1016/j.jasrep.2016.10.014. Cann, J.R., Renfrew, C., 1964. The characterization of obsidian and its application to the Mediterranean region. Proceedings of the Prehistoric Society, 30, 111-133. https://doi.org/10.1017/S0079497X00015097.

Carter, T., Grant, S., Kartal, M., Coşkun, A., Özkaya, V., 2013. Networks and Neolithisation: Sourcing obsidian from Körtik Tepe (SE Anatolia). J. Archaeol. Sci., 40(1), 556-569. https://doi.org/10.1016/j.jas.2012.08.003. 
Carter, T., Aubert, D., Brown, K., Doyle, S., 2012. Networking in the Neolithic: Obsidian Sourcing at Abu Hureyra (N. Syria). Poster at the Annual Meeting of the American Schools of Oriental Research, Chicago. http://maxlab.mcmaster.ca/ASOR\%20Abu\%20Hureyra\%20poster\%20final.pdf.

Carter, T., Campeau, K., Streit, K., 2020. Transregional Perspectives: Characterizing Obsidian Consumption at Early Chalcolithic Ein el-Jarba (N. Israel). J. of Field Archaeol., 45(4), 1-21. https://doi.org/10.1080/00934690.2020.1717857.

Chabot, J., Poidevin, J.L., Chataigner, C., Fortin, M., 2001. Caracterisation et provenance des artefacts en obsidienne de Tell'Atij et de Tell Gudeda (III millenaire, Syrie). Cahiers d'Acheologie Du CELAT, 10, 24.

Chataigner, C., 1998. Sources des artefacts du Proche Orient d'après leur caractérisation géochimique. In M.-C. Cauvin, A. Gourgaud, B. Gratuze, N. Arnaud, G. Poupeau, J.-L. Poidevin and C. Chataigner (eds.), L'obsidienne au Proche et Moyen Orient: du volcan à l'outil. BAR International Series 738, Oxford, pp. 273-324.

Chataigner, C., Gratuze, B., 2014a. New data on the exploitation of obsidian in the Southern Caucasus (Armenia, Georgia) and eastern Turkey, Part 1: Source characterization. Archaeometry, 56, 25-47. https://doi.org/10.1111/arcm.12006.

Chataigner, C., Gratuze, B., 2014b. New data on the exploitation of obsidian in the Southern Caucasus (Armenia, Georgia) and eastern Turkey, Part 2: Obsidian procurement from the Upper Palaeolithic to the Late Bronze Age. Archaeometry, 56, 48-69. https://doi.org/10.1111/arcm.12007. Chataigner, C., Işıklı, M., Gratuze, B., Çil, V., 2014. Obsidian Sources in the Regions of Erzurum and Kars (North-East Turkey): New Data. Archaeometry, 56, 351-374. https://doi.org/10.1111/arcm.12002.

Contenson, H.D., 1992. Préhistoire De Ras Shamra: Ras Shamra-Ougarit VIII. CNRS, Paris.

Craig, N., Speakman, R.J., Popelka-Filcoff, R.S., Glascock, M.D., Robertson, J.D., Shackley, M.S., Aldenderfer, M.S., 2007. Comparison of XRF and PXRF for analysis of archaeological obsidian from southern Perú, J. Archaeol. Sci. 34(12), 2012-2024. doi:10.1016/j.jas.2007.01.015.

Davis, M. K., Jackson, T.L., Shackley, M.S., Teague, T., Hampel, J., 2011. Factors affecting the EnergyDispersive X-Ray Fluorescence (EDXRF) analysis of archaeological obsidian, in: Shackley, M.S. (Ed.) XRay Fluorescence Spectrometry (XRF) in Geoarchaeology. Springer Publishing, New York, pp. 45-64. Drápalová, R., 2010. Petrographic and geochemical characterization of obsidian sources in Turkey: Petrografická a geochemická charakteristika zdrojů obsidiánu v Turecku (Diplomová práce (Master’s thesis)). Masarykova Univerzita V Brně. http://is.muni.cz/th/145070/prif_m/?lang=en;id=162553. 
Egami, N., Masuda, S.I., Gotoh, T., 1977. Tal-i Jarri A: A preliminary report of the excavations in Marv Dasht, 1961 and 1971. Orient, 13, 1-7. https://doi.org/10.5356/orient1960.13.1.

Epstein, S.M., 1977. The Trade in Near Eastern Obsidians. M.A. dissertation, University of Bradford. Forster, N., Grave, P., Vickery, N., Kealhofer, L., 2011. Non-destructive analysis using PXRF: methodology and application to archaeological ceramics. X-ray Spectrometry, 40(5), 389-398. https://doi.org/10.1002/xrs.1360.

Frahm, E., 2010. The Bronze-age Obsidian Industry at Tell Mozan (Ancient Urkesh), Syria. PhD thesis. Department of Anthropology, University of Minnesota. Available online at University of Minnesota's Digital Conservancy: http://purl.umn.edu/99753.

Frahm, E., 2013. Validity of "off-the-shelf" handheld portable XRF for sourcing Near Eastern obsidian chip debris. J. Archaeol. Sci., 40(2), 1080-1092. https://doi.org/10.1016/j.jas.2012.06.038.

Frahm, E., 2014a. Buying local or ancient outsourcing? Locating production of prismatic obsidian blades in Bronze-Age northern Mesopotamia. J. Archaeol. Sci., 41, 605-621. https://doi.org/10.1016/j.jas.2013.10.007.

Frahm, E., 2014b. Characterizing obsidian sources with portable XRF: Accuracy, reproducibility, and field relationships in a case study from Armenia. J. Archaeol. Sci., 49, 105-125. https://doi.org/10.1016/j.jas.2014.05.003.

Frahm, E., 2016. Can I get chips with that? Sourcing small obsidian artifacts down to microdebitage scales with portable XRF. J. Archaeol. Sci.: Reports, 9, 448-467.

https://doi.org/10.1016/j.jasrep.2016.08.032

Frahm, E., 2020. Variation in Nemrut Dağ obsidian at Pre-Pottery Neolithic to Late Bronze Age sites (or: All that's Nemrut Dağ obsidian isn't the Sıcaksu source). J. Archaeol. Sci.: Reports, 32, 102438. https://doi.org/10.1016/j.jasrep.2020.102438.

Frahm, E., Doonan, R.C.P., Kilikoglou, V., 2014a. Handheld portable X-ray fluorescence of Aegean obsidians. Archaeometry, 56(2), 228-260. https://doi.org/10.1111/arcm.12012.

Frahm, E., Schmidt, B.A., Gasparyan, B., Yeritsyan, B., Karapetian, S. Meliksetian, K., Adler, D.S., 2014b. Ten seconds in the field: rapid Armenian obsidian sourcing with portable XRF to inform excavations and surveys. J. Archaeol. Sci., 41, 333-348. https://doi.org/10.1016/j.jas.2013.08.012. Frahm, E., Campbell, S., Healey, E., 2016. Caucasus connections? New data and interpretations for Armenian obsidian in Northern Mesopotamia. J. Archaeol. Sci.: Reports, 9, 543-564.

https://doi.org/10.1016/j.jasrep.2016.08.023 
Francaviglia, V., 1994. L'origine des outils en obsidienne de Tell Magzalia, Tell Sotto, Yarim Tepe et Kül Tepe, Iraq. Paléorient, 20(2), 18-31. https://doi.org/10.3406/paleo.1991.4550.

Gratuze, B., Zambello, M., 2014. Analyse physico-chimique de I' outillage en obsidienne de Tell Beydar (Djézireh syrienne, Âge du Bronze), in: Milano, L. and Lebeau, M. (Eds.), Tell Beydar Environmental and Technical Studies. Volume II. Brepols, Turnhout, pp. 117-122.

Govindaraju, K., 1994. Compilation of Working Values and Sample Description for 383 Geostandards. Geostandard. Newsl., 18(S1), 1-158. https://doi.org/10.1046/j.1365-2494.1998.53202081.x-i1. Jochum, K. P., Nohl, U., Herwig, K., Lammel, E., Stoll, B., Hofmann, A. W., 2005. GeoReM: a new geochemical database for reference materials and isotopic standards. Geostandards and Geoanalytical Res., 29(3), 333-338. https://doi.org/10.1111/j.1751-908X.2005.tb00904.x. Kartal, M., Kartal, G., Coşkun, A., Carter, T., Şahin, F., Özkaya, V., 2018. Chipped stone assemblages of Körtik Tepe (Turkey). J. Archaeol. Sci.: Reports, 19, 92-99.

https://doi.org/10.1016/j.jasrep.2018.02.017

Khalidi, L., Oppenheimer, C., Gratuze, B., Boucetta, S., Sanabani, A., al-Mosabi, A., 2010. Obsidian sources in highland Yemen and their relevance to archaeological research in the Red Sea region. J. Archaeol. Sci., 37(9), 2332-2345. http://doi.org/10.1016/j.jas.2010.04.007

Khalidi, L., Gratuze, B., Stein, G., McMahon, A., Al-Quntar, S., Carter, R., Cuttler, R., Dreshchler, P., Healey, E., Inizan, M.-L., Mouralis, D., Pernicka, E., Robin, A.-K., 2016. The growth of early social networks: New geochemical results of obsidian from the Ubaid to Chalcolithic Period in Syria, Iraq and the Gulf. J. Archaeol. Sci.: Reports, 9: 743-757. http://dx.doi.org/10.1016/j.jasrep.2016.06.026 Kuschke, A., 1962. Bericht über eine sondage im palestgarten von Ugarit-Ras Shamra, in : Schaeffer, C.F.-A. Ugaritica. IV: Découvertes des 18e et 19e campagnes, 1954-1955: fondements préhistoriques d'Ugarit et nouveaux sondages, études anthropologiques, poteries grecques et monnaies islamiques de Ras Shamra et environs.Imprimerie Nationale, Paris, pp. 17-299

Le Bourdonnec, F.-X., Bellot-Gurlet, L., Dillmann, P., Poupeau, G., Lugliè, C., Bressy-Leandri, C., 2013. P-XRF: quelles limites pour les études de provenance d'obsidienne en Méditerranée occidentale? In: XIXe Colloque du GMPCA, 238.

Le Bourdonnec, F.-X., Bellot-Gurlet, L., Luglié, C., Bressy-Leandri, C., 2015. Archéométrie de l'obsidienne: déchiffrer la circulation d'une matière première. Les nouvelles de l'archéologie 138. https://doi.org/10.4000/nda.2722. Maeda, O., 2003. Prehistoric obsidian distribution in the Rouj Basin, In: Iwasaki, T., Tsuneki, A. (Eds) Archaeology in the Rouj Basin Vol. 1: Regional Study of the Transition from Village to City in 
Northwest Syria. University of Tsukuba, Department of Archaeology, Institute of History and Anthropology, Tsukuba, pp. 167-184.

Maeda, O., 2010. Recent Studies on the Use of Obsidian in the Neolithic Near East. Journal of West Asian Archaeology, 11, 67-79.

Milić, M., 2014. PXRF characterisation of obsidian from central Anatolia, the Aegean and central Europe. J. Archaeol. Sci., 41, 285-296. https://doi.org/10.1016/j.jas.2013.08.002.

Milić, M., 2016. A question of scale? Connecting communities through obsidian exchange in the Neolithic Aegean, Anatolia and Balkans, In: Molloy, B. (Ed.), Of Odysseys and Oddities: Scales and Modes of Interaction Between Prehistoric Aegean Societies and Their Neighbours. Oxbow Books, Oxford, pp. 97-122.

Millhauser, J.K., Fargher, L.F., Heredia Espinoza, V.Y., Blanton, R.E., 2015. The geopolitics of obsidian supply in Postclassic Tlaxcallan: A portable X-ray fluorescence study. J. Archaeol. Sci., 58, 133-146. https://doi.org/10.1016/j.jas.2015.02.037 .

Mouralis, D., Massussi, M., Palumbi, G., Akköprü, E., Balossi Restelli, F., Brunstein, D., Frangipane, M., Gratuze, B., Mokadem, F., Robin, A.-K., 2018. The procurement of obsidian at Arslantepe (Eastern Anatolia) during the Chalcolithic and Early Bronze Age: Connections with Anatolia and Caucasus. Quat. Int., 467, Part B, 342-359. https://doi.org/10.1016/j.quaint.2017.11.041 Nazaroff, A.J., Prufer, K.M.. Drake, B.L., 2010. Assessing the applicability of portable X-ray fluorescence spectrometry for obsidian provenance research in the Maya lowlands. J. Archaeol. Sci.. 37(4), 885-895. https://doi.org/10.1016/j.jas.2009.11.019.

Orange, M., Carter, T., Le Bourdonnec, F.-X. (2013). Sourcing obsidian from Tell Aswad and Qdeir 1 (Syria) by SEM-EDS and EDXRF: Methodological implications. Comptes Rendus Palevol, 12(3), 173180. https://doi.org/10.1016/j.crpv.2012.11.001.

Parker, B.J., (Ed.) forthcoming. The Upper Tigris Archaeological Research Project: The Ubaid Period at Kenan Tepe. Cotsen Institute of Archaeology Press, Los Angeles.

Parker, B.J., Dodd, L., Creekmore, A., Healey, E., Painter., C., 2006. The Upper Tigris Archaeological Research Project (UTARP): A preliminary report from the 2003 and 2004 field seasons. Anatolica, 32, 71-151.

Parker, B.J., Foster, C.P., Nicoll, K., Kennedy, J.R., Graham, P., Smith, A., Hopwood, D.E., Hopwood, M., Butler, K., Healey, E., Uzel, M.B., Jensen, R., 2009. The Upper Tigris Archaeological Research Project (UTARP): A preliminary report from the 2007 and 2008 field seasons at Kenan Tepe. Anatolica, 35, 85-152. 
Pernicka, E., Keller, J., Cauvin, M.-C., 1997. Obsidian from Anatolian sources in the Neolithic of the middle Euphrates Region (Syria). Paléorient, 23(1), 113-122.

Phillips, S.C., Speakman, R. J., 2009. Initial source evaluation of archaeological obsidian from the Kuril Islands of the Russian Far East using portable XRF. J. Archaeol. Sci., 36 (6), 1256-1263. https://doi.org/10.1016/j.jas.2009.01.014.

Renfrew, C., Dixon, J., 1976. Obsidian in western Asia: a review, In: Longworth, I., Sieveking, G., Wilson, K.E. (Eds.), Problems in economic and social archaeology.Duckworth, London, pp. 137-150 Renfrew, C., Dixon, J.E. Cann, J.R., 1966. Obsidian and early cultural contact in the Near East. Proceedings of the Prehistoric Society, 32, 30-72. https://doi.org/10.1017/S0079497X0001433X. Robin, A. K., Mouralis, D., Akköprü, E., Gratuze, B., Kuzucuoğlu, C., Nomade, S., Khalidi, L., 2016. Identification and characterization of two new obsidian sub-sources in the Nemrut volcano (Eastern Anatolia, Turkey): The Sıcaksu and Kayacık obsidian. J. Archaeol. Sci.: Reports, 9, 705-717. https://doi.org/10.1016/j.jasrep.2016.08.048.

Schneider, G., 1990. Herkunft von obsidian artefacteten in Uruk. Baghdader Mitt., 26, 67-72.

Sheppard, P., Trichereau, B., Milicich, C., 2010. Pacific obsidian sourcing by portable XRF, Archaeol. in Oceania, 45(1), 21-30. https://doi.org/10.1002/j.1834-4453.2010.tb00074.x.

Shackley, M.S., 1998. Current Issues and Future Directions in Archaeological Volcanic Glass Studies: An Introduction, In: Shackley, M.S. (Ed.) Archaeological Obsidian Studies: Method and Theory. Plenum Press, New York, pp. 1-14

Tykot, R.H., 2011. Obsidian finds on the fringes of the Central Mediterranean: exotic or eccentric exchange? In: Vianello, A. (Ed.), Exotica in the Prehistoric Mediterranean. Oxbow Books, Oxford, pp. $33-44$.

Wright, G.A., 1968. Obsidian Analyses and early trade in the Near East: 7500 toO 3500 B.C. PhD thesis. University of Michigan.

Wright, G.A., 1969. Obsidian Analysis and Prehistoric Near Eastern Trade: 7500 to 3500 BC. University of Michigan Museum of Anthropology Anthropological Papers, 37. University of Michigan, Ann Arbor. 


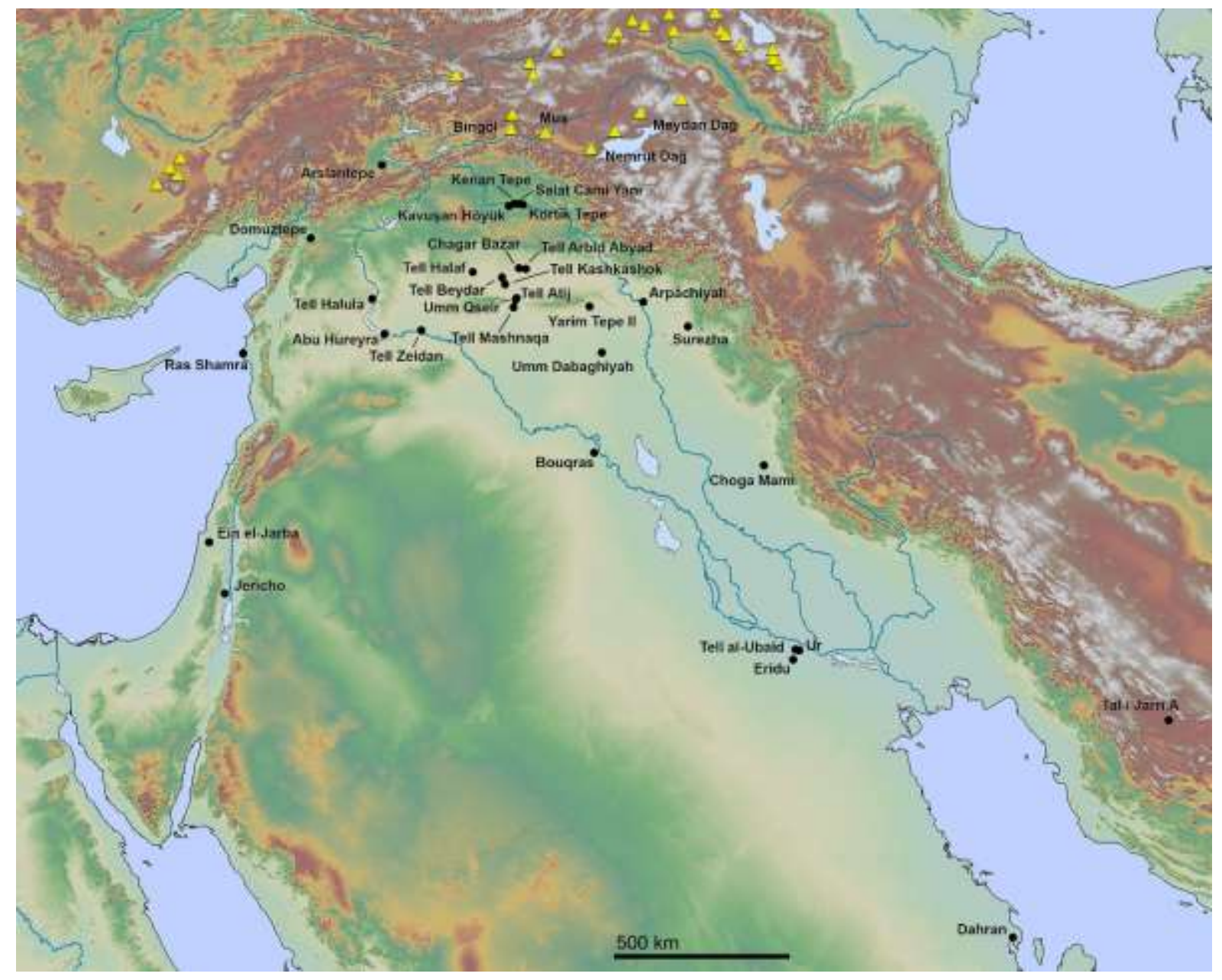

Fig.1 

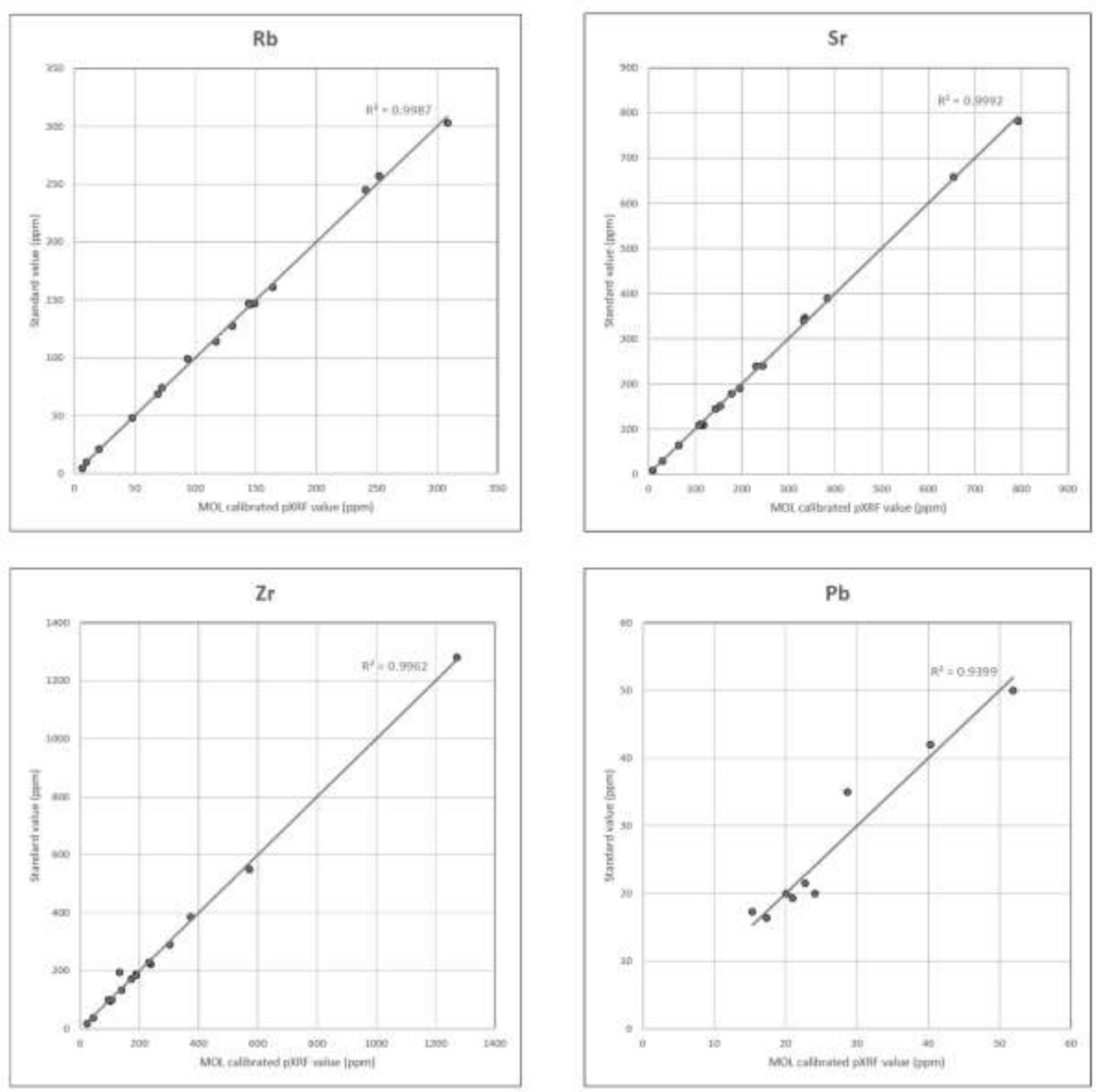

Fig. 2 


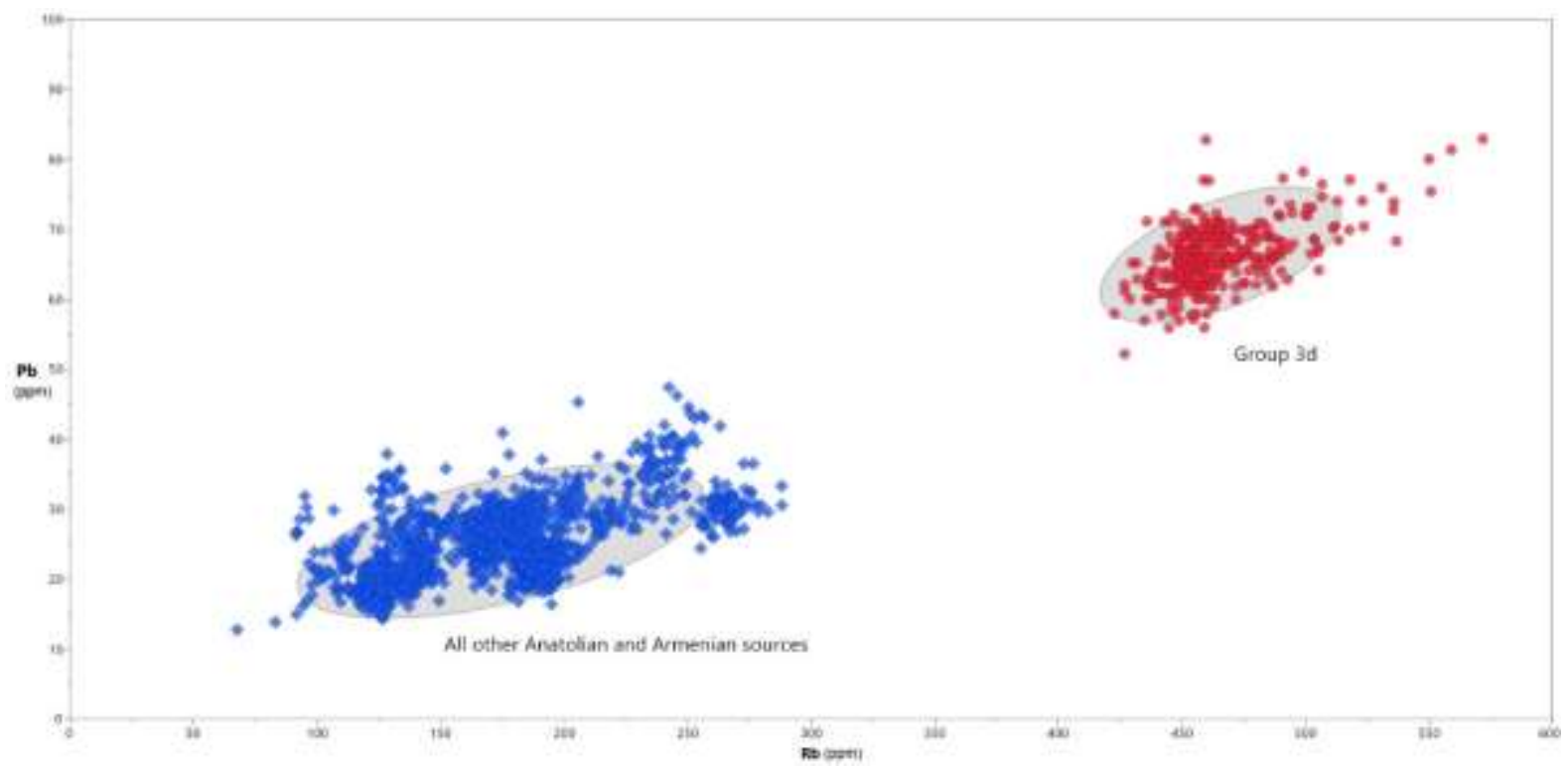

Fig. 3a

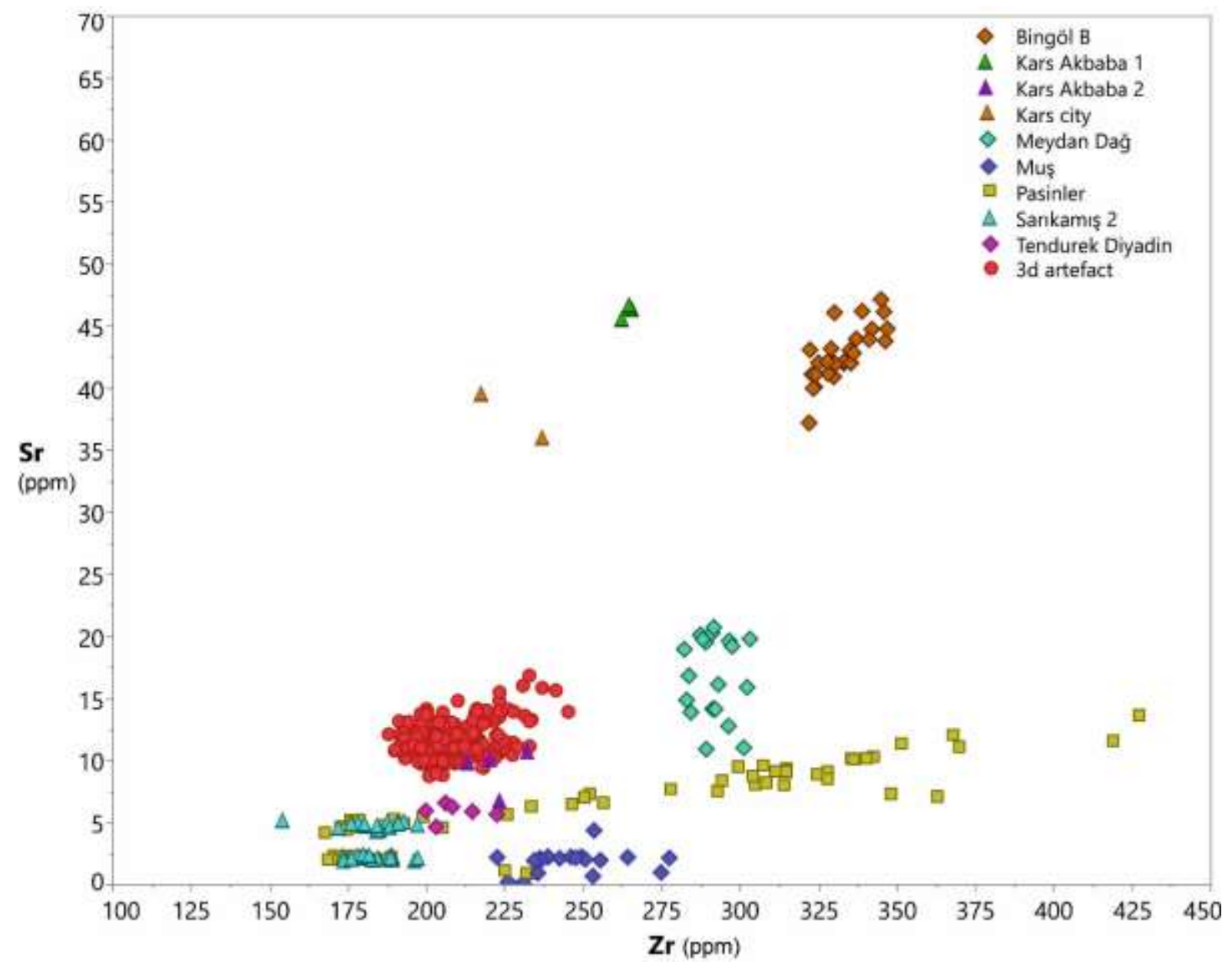

Fig. 3b 

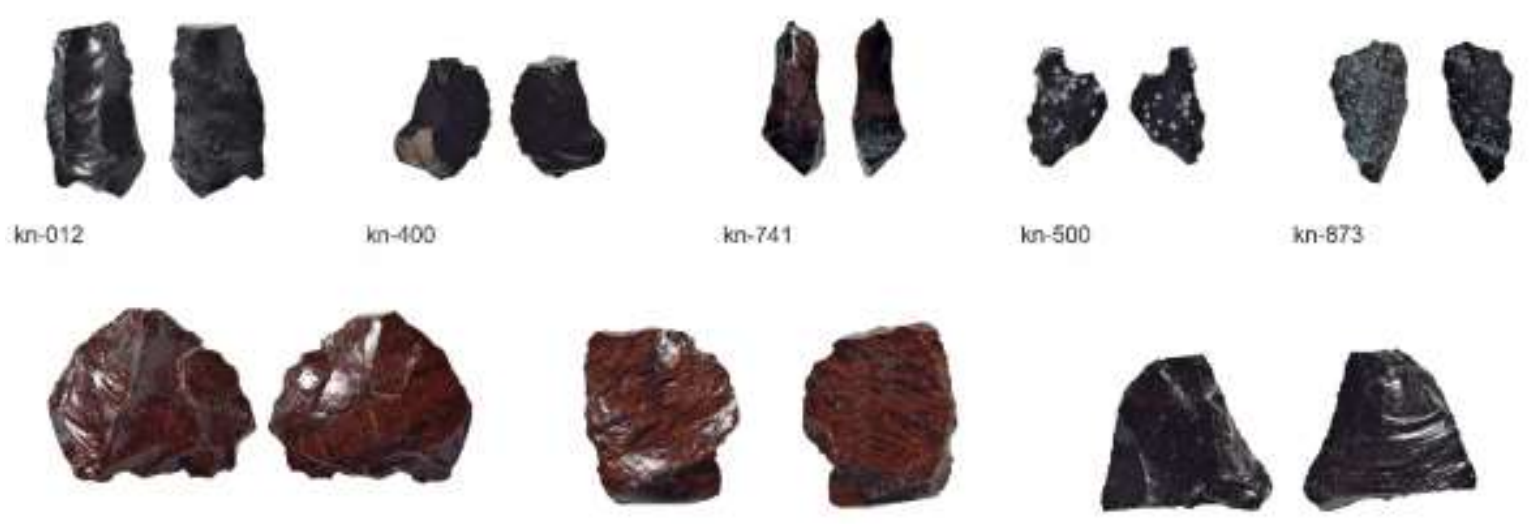

$k n-306$

kn-381

kn- 406

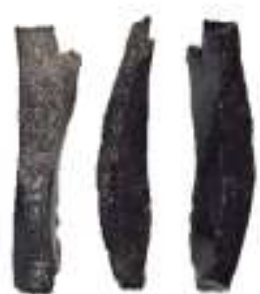

$k n-403$

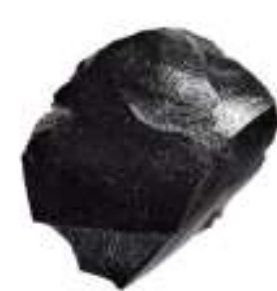

kn-388
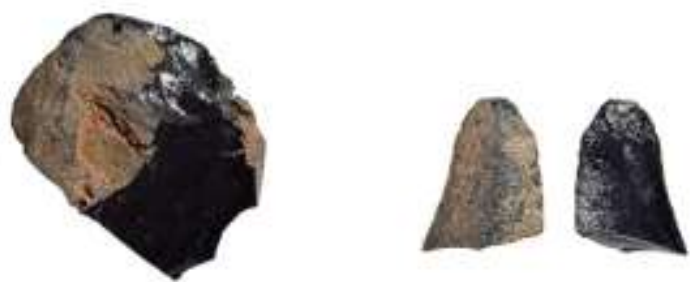

kn-690

$2 \mathrm{em}$
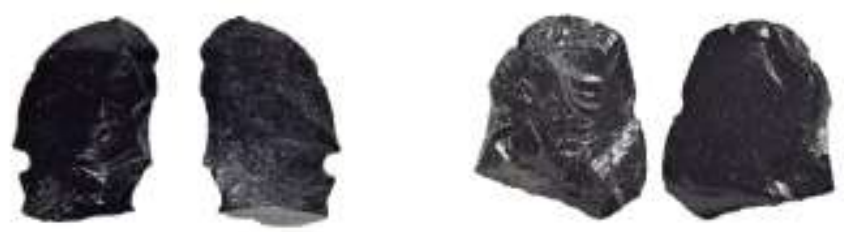

kn-307
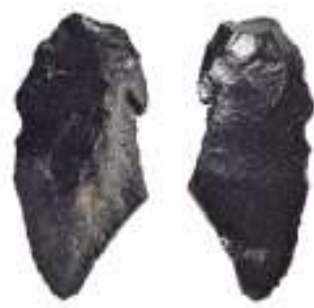

sn -001

kn-319

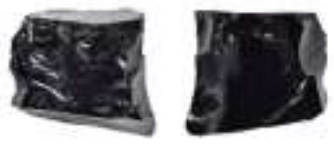

kn-034
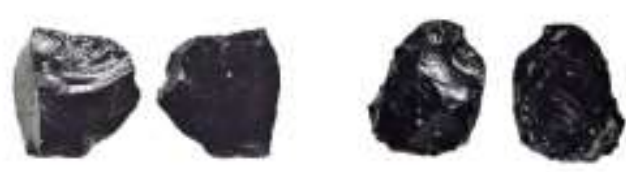

kn-418

$\mathrm{kn}-\mathrm{B2} 8$

Fig. 4 


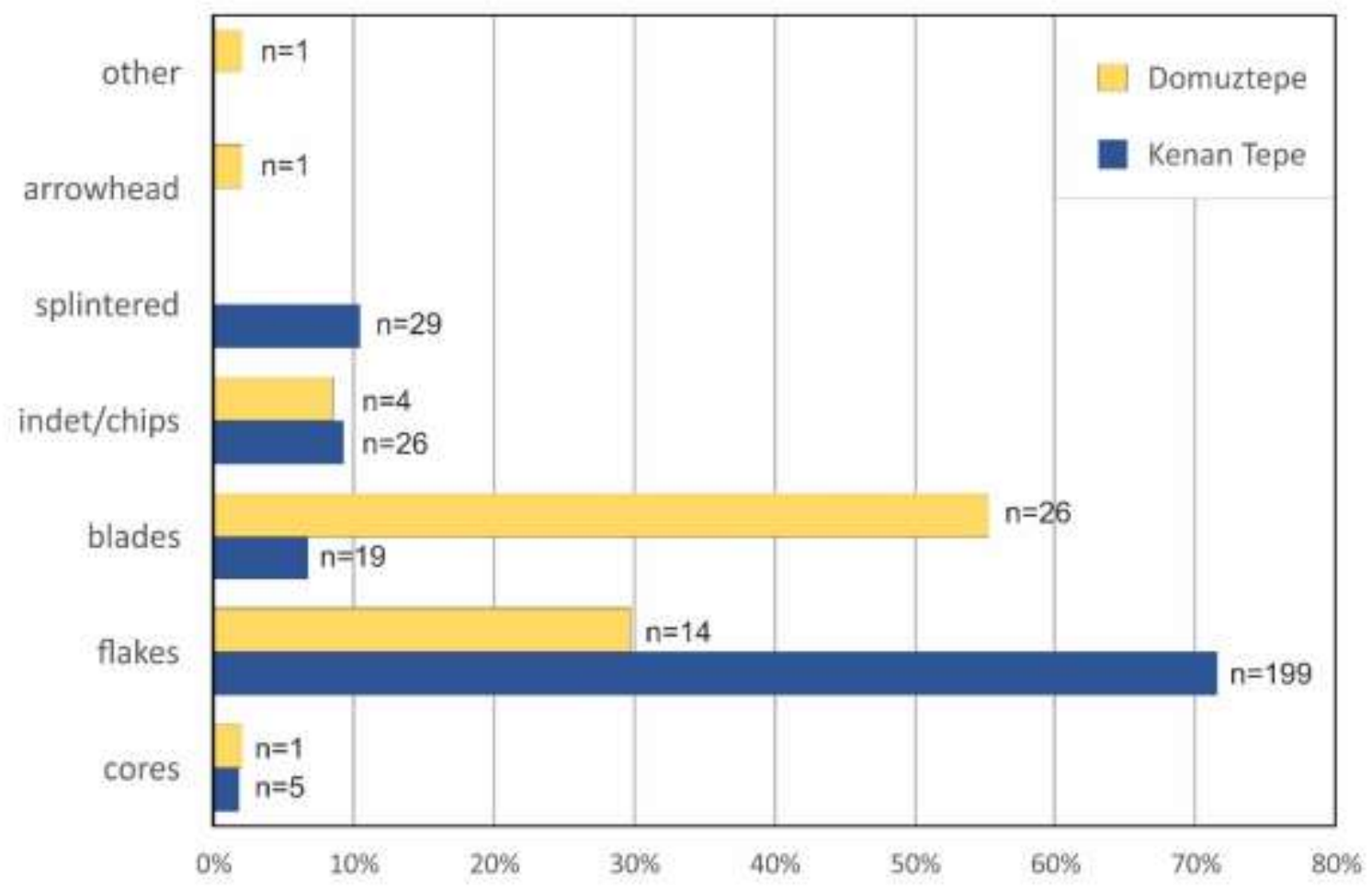

Fig. 5

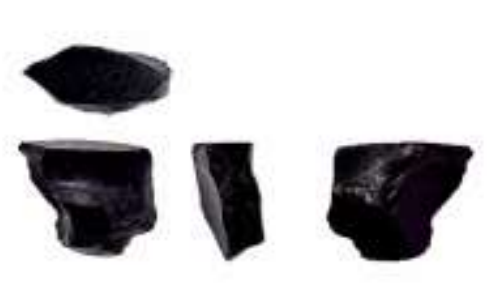

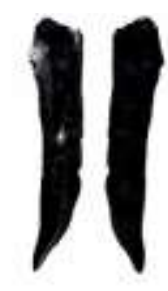

att-1446

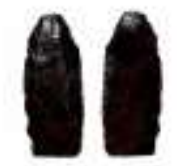

dt-o152

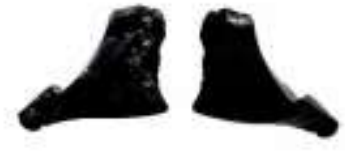

dt-015a:

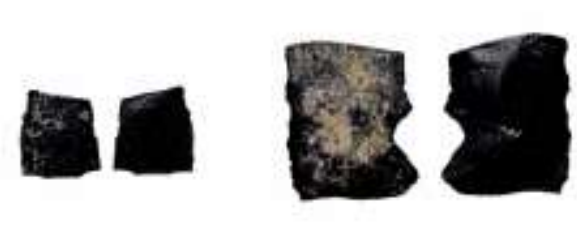

dt -0169 at -0160

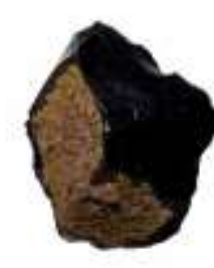

d- -01 te

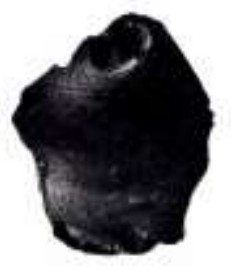

물

dt-0187

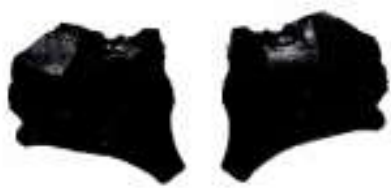

at 0200

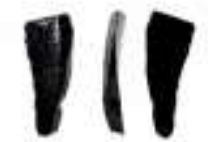

c1. 0239

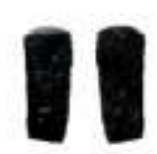

th. 0241

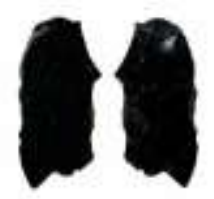

di. 0242

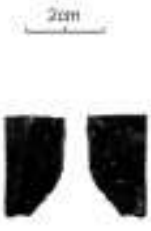

ct. 0245

Fig. 6 


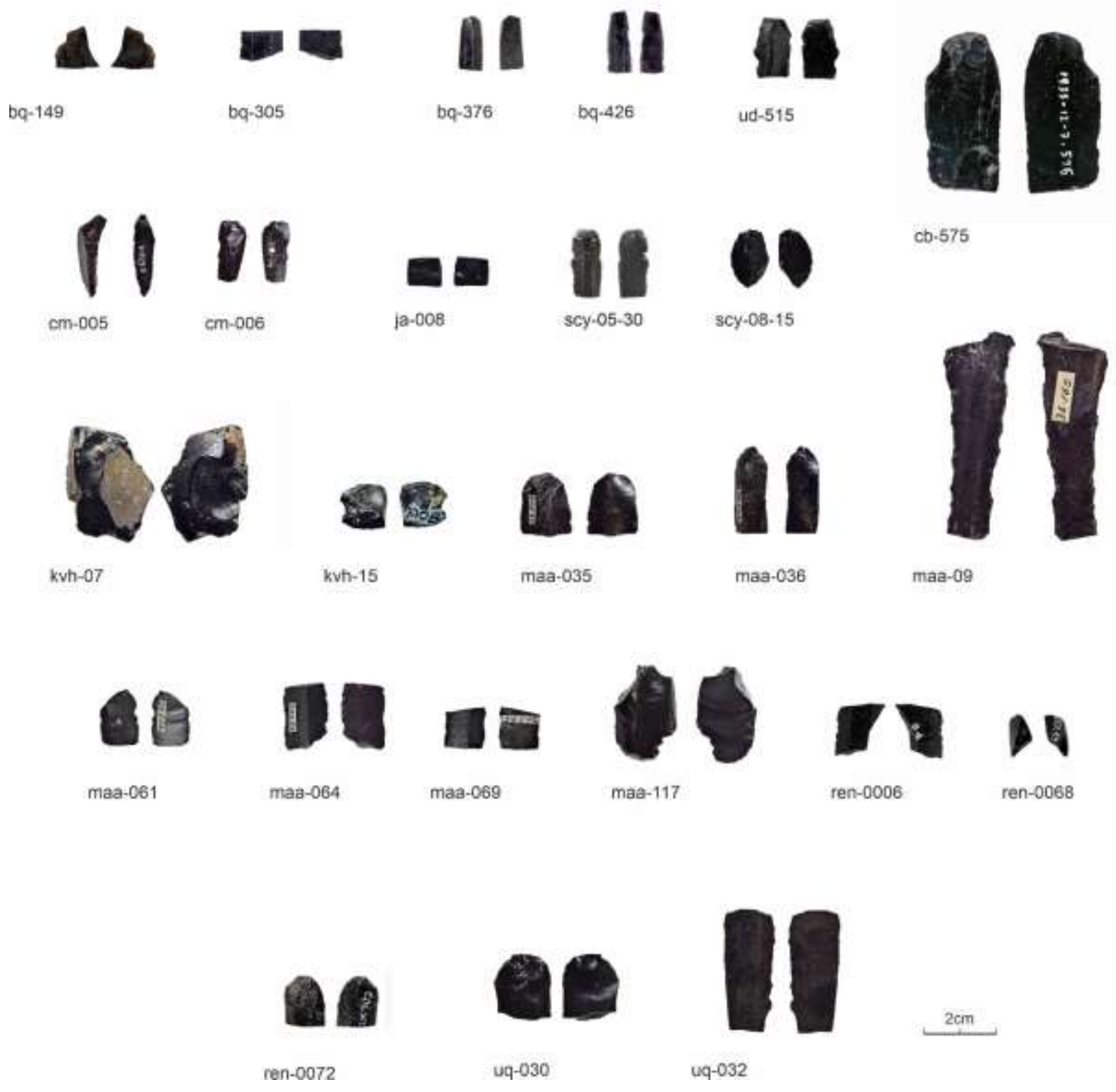

Fig. 7 